Vol. 2, No. 2, 2020

https://doi.org/10.23939/jtbp2020.02.113

Volodymyr Yehorchenkov, Oleh Sergeychuk, Lidiia Koval

\title{
PRINCIPLES OF THE EXPOSURE NATURAL LIGHTING MODELING OF PREMISES
}

\author{
Kyiv National University of Construction and Architecture, \\ Department of Architectural Structures, \\ egval@ukr.net
}

(c) Yehorchenkov V., Sergeychuk O., Koval L., 2020

It's well known that a criterion of estimating the varying natural lighting is exposure equal to the product of light intensity by its duration. Here we have made studies into the exposure in the room depending on the orientation of a light aperture and its location in space. The exposure has been considered by the example of three identical office rooms with the same light apertures oriented north, west and south and having three positions - vertical, inclined and horizontal. To calculate the annual exposure we made use of the well-known software package VELUX Daylight Visualizer 2. For convenience of analyzing the exposure there was introduced the concept of the natural exposure coefficient (NEC) which is a ratio between the exposure in the room and a simultaneous value of the outer exposure. Our studies have shown that exposure is an effective criterion to assess the indoor natural lighting in time. The existing system of estimating energy consumption in lighting buildings with the help of a simultaneous lighting is rough and does not take into account such factors as orientation of light apertures by the sides of the horizon and their location in space. The use of exposure let us improve the method of calculating energy consumption in lighting premises taking into account the light aperture location in space and their as orientation by the sides of the horizon. The numerical experiment performed has given a predicted result, namely, the most power-consuming room is the north-oriented one with the vertical light aperture and the least power-consuming room is the one with the horizontal light aperture. The room with the inclined light aperture has average energy consumption.

Key words: exposure, light aperture, offices, natural exposure coefficient (NEC), illumination, energy consumption

\section{Introduction}

The purpose of creating comfort light conditions is first and foremost to satisfy the visual needs of a person. Having solved this problem, one can develop the systems of lighting buildings. The main light consumer is a person's eye. The comfort light environment parameters must be close to the optimal range within which a person spends the minimum of the biological energy (Chernova \& Bylova, 2004). The parameters being above or below this range, the perception conditions are not satisfactory. So, the lighting systems are only power efficient when the light environment parameters are within a favorable range or close to it.

Analysis of the research in the sight physiology of sight has shown that the process of our light perception depends not only on the parameter intensity but on its duration too. As early as the 18-th century the scientists put forward the hypotheses of the constancy of the irritant $I$ value multiplied by its duration $t$ when the same visual effect is obtained (Kravkov, 1950). The stronger the irritant, the less time is needed to visualize a signal. And vice versa. That is if $I \times t=A$, where $A$ is some constant. The criterion characterizing the light potential which combines the level of the light value and its duration over some 
definite period is called the lighting exposure and it can be used to estimate the conditions of day lighting in premises with time changes being taken into account (Yegorchenkov, 2009). Some researchers state that it is the exposure which must be taken as the normalizable index. For example, in his researches Ioffe K.S. (Ioffe, 2008) sates that when rationing the lighting in premises one should use the exposure on the eye pupil but not the illumination on a horizontal plane as a criterion of estimating. In this case both the hypothalamic structures and the whole organism are synchronized and the energetic characteristics of lighting systems are optimized. Unfortunately, there is no time factor in rating the natural lighting both in the domestic (DBN V.2.5-28:2018) and foreign norms (SNiP 23-05-10; PN-71/B02380; Darula, 2019). And so it is difficult to estimate the energetic indices to determine the class of the energy efficiency of buildings.

\section{Target of this article}

The purpose of this work is to develop the principles of the light conditions taking into account the time factor in the form of an annual exposure to estimate the energetic indices of the building lighting systems.

\section{Techniques used}

The principles of modeling are considered by the examples of three identical offices as large as $6.15 \times 3.0 \mathrm{~m}$ in plan with the same light apertures of $1.32 \times 2.1 \mathrm{~m}$ (see Fig. 1) oriented north, west and south and having three positions - vertical (the inclination angle of $90^{\circ}$ ), inclined (the inclination angle of $45^{\circ}$ ) and horizontal (the inclination angle of $0^{\circ}$ ). To calculate the annual exposure we have made use of the well-known software package VELUX Daylight Visualizer 2 with the help of which we have calculated the distribution of lighting characteristics at the calculation point (CP) in the room on round the clock and then round the year. The calculated day was the $21^{\text {st }}$ day of each month, the model of a semi-clear (something between cloudy and clear) sky for the conditions in Kiev being used (CIE S 011/E:2003). The CP was in the center of the room as high as $0.85 \mathrm{~cm}$ above the floor level.
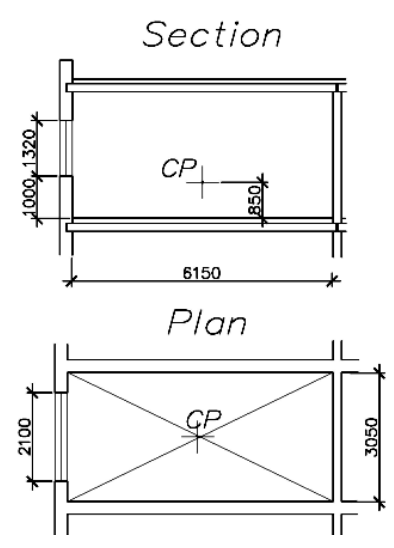

$a$
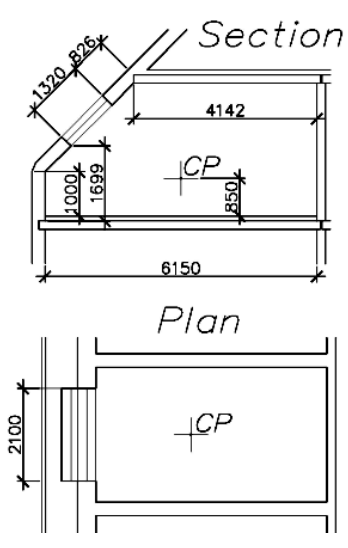

$b$

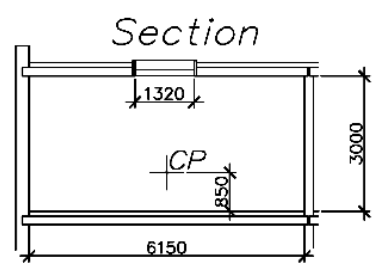

Plan

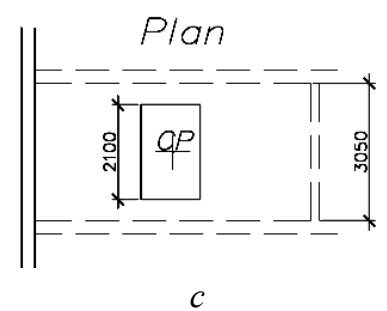

Fig. 1. Models of premises for the exposure analysis: a - with the vertical aperture; $b$ - with the inclined aperture; $c$ - with the horizontal aperture

For convenience of analyzing the exposure there was introduced the concept of the natural exposure coefficient (NEC) which is a ratio between the exposure in the room $E X_{D}$ and a simultaneous value of the outer exposure $E X_{L}$, 


$$
K_{e x}=\frac{E X_{D}}{E X_{L}} 100 \% .
$$

The results of the NEC calculation are given by the month in Fig. 2.

As is evident from the data obtained, the values of the NEC for all light apertures of different orientations have the same distribution pattern by the month. For the warmer months (from March-April to September-October), the coefficient has practically a constant value, while in the colder months there is a sharp jump up. The reason is that at this period the duration of external illumination as well as its absolute levels sharply decreases. The NEC is necessary to calculate the operating time of the artificial lighting system.

The scientific novelty lies in the fact it's for the first time that the natural lighting in premises is suggested to be evaluated by exposure which combines the levels of natural illumination and its lifetime. That provides answers to many lighting engineering, normative and energetic problems.

The practical significance consists in the fact that the lighting engineering (illumination, intensity) and energetic (solar radiation, energy consumption) characteristics are immediately determined in time and in this way the most effective system of lighting is discovered.

It's well known that energy consumption for lighting premises depends on the length of artificial lighting, which in its turn is greatly influenced by the length of natural lighting. The latter to be determined, one should calculate the values of the annual exposure $E X_{D}, \mathrm{klux} \cdot \mathrm{h}$, the natural lighting in the room from the light apertures differently located in space and the corresponding orientation at the critical internal illumination equal to 100 lux. To do this, the above mentioned software package VELUX Daylight Visualizer 2 complex and other complexes can be used (Jacobs, 2012; Larson, 1998). From the reference information (SNiP II-A.6-72) there are taken the data about the scattered natural external illumination for a corresponding construction area and the external summer exposure $E X_{L}, \mathrm{klux} \cdot \mathrm{h}$, is determined, with the critical external illumination being equal to $5000 \mathrm{lux}$. And here the length of natural lighting $t_{L}, \mathrm{~h}$, under the open sky is easily determined. It's evident here that the length of natural lighting in the room exposure $t_{D}$, h will be proportional to the length under the open sky $t_{L}, \mathrm{~h}$. Then the length of natural lighting in a room can be found out from the following proportion.

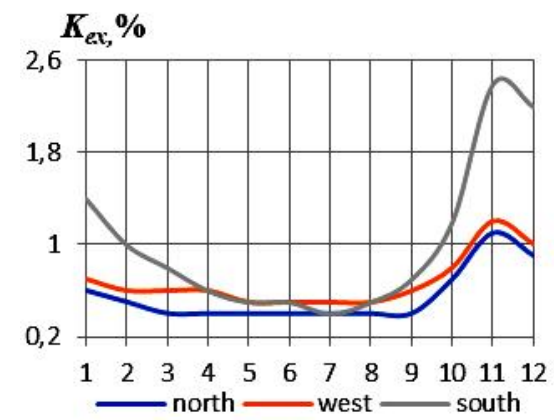

$a$

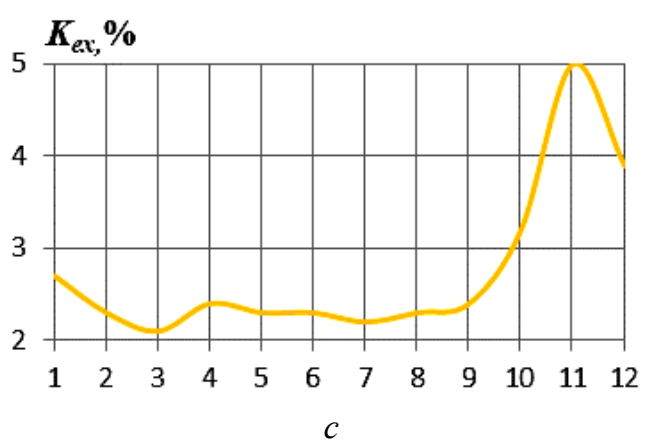

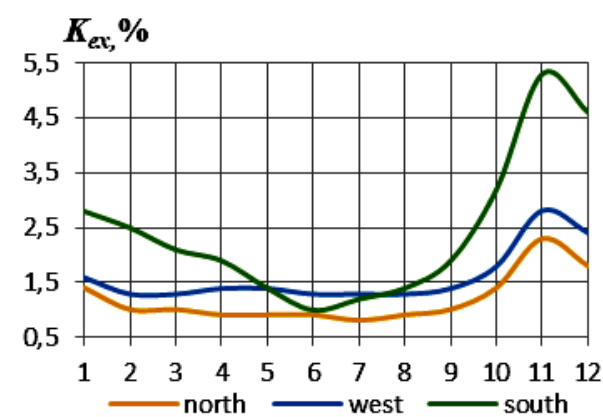

$b$

Fig. 2. Dependence of the NEC on the light aperture location: a-vertical;

$b$-inclined; $c$-horizontal and on its orientation on the sides of the horizon (the colour) 


$$
\frac{E X_{D}}{t_{D}}=\frac{E X_{L}}{t_{L}} ; \quad t_{D}=\frac{E X_{D} \cdot t_{L}}{E X_{L}} ; \quad t_{D}=0.01 K_{e x} t_{L} .
$$

In this way the length of natural lighting in a room was determined at different locations of light apertures (Table 1).

Table 1

\section{The Length of the Natural Lighting in a Room} at Different Locations of Light Apertures

\begin{tabular}{|c|c|c|c|c|c|c|c|}
\hline \multicolumn{8}{|c|}{ Length, hour/year at the following locations of light apertures } \\
\hline \multicolumn{2}{|c|}{ Vertically, oriented } & \multicolumn{3}{c|}{ Inclined, oriented } & \multicolumn{3}{c|}{ Horizontally, the orientation } \\
\hline North & West & South & North & West & South & latitudinal & meridional \\
\hline 2209 & 2723 & 2941 & 3758 & 3855 & 3672 & 3995 & 3998 \\
\hline
\end{tabular}

From the Table it's clear that only at the vertical north-oriented light aperture the value of the annual time of using the natural lighting approximately coincides with the normative one (DSTU B A.2.2-12:2015), in other cases it is much higher.

Now let's consider how the time of duration of artificial lighting will change when using the data of Table 1 . To do this, it's necessary to determine the lifetime of the artificial lighting system during a year. If we arbitrarily assume that the duration of the working time of two shifts in an office is $t_{W}=4300 \mathrm{~h} \mathrm{a}$ year, then the length of artificial lighting, $t_{N}$, h, is equal to the difference

$$
t_{N}=t_{W}-t_{D}
$$

Table 2

The Length of Artificial Lighting in a Room at Different Locations of Light Apertures at the Two-Shift Operating Schedule of an Office

\begin{tabular}{|l|c|c|c|c|c|c|c|}
\hline \multicolumn{7}{|c|}{ Length, hour/year at the following locations of light apertures } \\
\hline Vertically, oriented & \multicolumn{3}{c|}{ Inclined, oriented } & \multicolumn{3}{c|}{ Horizontally, the orientation } \\
\hline North & West & South & North & West & South & latitudinal & meridional \\
\hline 2091 & 1577 & 1359 & 542 & 445 & 628 & 305 & 302 \\
\hline
\end{tabular}

The results of calculating the energy consumption to lighten all variants of the light aperture locations at the normative artificial illumination of 300 lux are given in Table 3.

Table 3

\section{Calculation of Energy Consumption to Lighten All Variants of the Light Aperture Locations in a Room}

\begin{tabular}{|c|c|c|c|c|c|c|c|}
\hline \multicolumn{8}{|c|}{ Energy Consumption, KWt $\cdot h$, at the following locations of light apertures } \\
\hline \multicolumn{3}{|c|}{ Vertically, oriented } & \multicolumn{2}{|c|}{ Inclined, oriented } & \multicolumn{2}{c|}{ Horizontally, the orientation } \\
\hline North & West & South & North & West & South & latitudinal & meridional \\
\hline 489 & 348 & 293 & 127 & 99 & 129 & 66 & 65 \\
\hline & & \multicolumn{6}{c}{ The value of energy consumption by the } \\
DSTU B A. 2.2-12:2015 \\
\hline
\end{tabular}

As seen from the Table the method of calculating the energy consumption given in (DSTU B A.2.2-12:2015) makes it possible to calculate only for one variant of the light aperture location in a room (judging from the data obtained, for the vertical north-west or north-east oriented light aperture). 


\section{Conclusions}

1. In the article there is put forward a principle of determining the length of artificial lighting on the base of exposure at a different light aperture location in space which greatly influences the energy consumption to lighten premises.

2. As a result of the numerical experiment performed the predicted result has been obtained, namely: the most power-consuming room is the one with the vertical north-oriented light aperture, while the least power-consuming room is the one with the horizontal light aperture. The room with the inclined light aperture is in the between position.

\section{References}

Chernova, N. M., Bylova, A. M. (2004). General Ecology. Moscow: Izdatel'stvo Drofa.

Kravkov, S. V. (1950). Eye and its Action. Moscow-Leningrad: Izdatel'stvo AN USSR.

Yegorchenkov V. (2009). Modelling of Natural Lighting of Building with Taking into Account the Time characteristics. Proc. VI Intern. Conf. Kharkov, 159-163.

Ioffe K. I. (2008). Biological Influence of Visual Light on a Human Being's Organism. Svitlotekhnika and Elektroenergetika, No. 3, 21-29.

Natural and artificial lighting, DBN V.2.5-28:2018. State Building Codes of Ukraine (2018). Kyiv: Ukrarkhbudinform (in Ukrainian).

Natural and artificial lighting, SNiP 23-05-10. State Building Codes of Russian (2011). Moscow (in Russian).

PN-71/B-02380/ Oswietlenie wnetrz swiatlem dziennym.

Darula S. (2019). Review of the Up-to-Date State and Perspectives of Standardization in the Field of Natural Indoor Lighting. Svetotekhnika, No. 6, 6-20.

Spatial distribution of daylight - CIE standard general sky: CIE S 011/E:2003 (ISO 15469:2004(E)) (2003). Vienna: CIE Central Bureau Vienna (CIE draft standard).

Jacobs A. (2012). Radiance Cookbook. 24 January, 2012.

Larson G. (1998). Silicon Graphics, Inc Rendering with Radiance: A Practical Tool for Global Illumination ACM Siggraph'98 Course No. 33 Orlando, FL July 21, 1998.

Building Climatology and Geophysics. SNiP II-A.6-72 (1973). Moscow: Stroiizdat (in Russian).

Energetic Efficiency of Buildings. Methods of Calculating the Energy Consumption at Warming, Cooling, Ventilation, Lighting and Hot Water Supply: DSTU B A.2.2-12:2015 (2015). Kyiv: Ukrarkhbudinform (in Ukrainian).

В. О. Сгорченков, О. В. Сергейчук, Л. М. Коваль Київський національний університет будівництва і архітектури, кафедра архітектурних конструкцій

\section{ПРИНЦИПИ МОДЕЛЮВАННЯ ПРИРОДНОГО ОСВІТЛЕННЯ ПРИМІЩЕНЬ ЗА ЕКСПОЗИЦІЕЮ}

(ㄷ) Сгорченков В. О., Сергейчук О. В., Коваль Л. М., 2020

Відомо, що критерієм оцінки змінного природного освітлення є експозиція, яка дорівнює добутку інтенсивності освітлення на час його дії. Метою роботи є розробка принципів моделювання світлового режиму з урахуванням часового чинника у вигляді річної експозиції при оцінці енергетичних показників від систем освітлення будівлі. Проведено дослідження експозиції в приміщенні залежно від орієнтації світлопрорізу і його розташування в просторі. Експозиція розглянута на прикладі трьох однакових офісних приміщень $з$ однаковим світлопрорізом, який має три орієнтації: північ, захід і південь та три положення: вертикальне, похиле і горизонтальне. Для розрахунку річної експозиції використаний відомий програмний комплекс VELUX Daylight Visualizer 2. Для зручності аналізу експозиції введено поняття 
коефіцієнта природної експозиції (КПЕ), який є відношенням експозиції в приміщенні до одночасного значення зовнішньої експозиції. Дослідження показали, що експозиція є ефективним критерієм оцінки природного освітлення в приміщеннях у часі. Існуюча система оцінки енергоспоживання при освітленні будинків системою суміщеного освітлення $є$ наближеною і не враховує таких факторів, як орієнтація світлопрорізів за сторонами горизонту і їхне положення в просторі. Удосконалено метод розрахунку енергоспоживання при освітленні приміщень з використанням експозиції, який враховує розташування світлопрорізів у просторі та їх орієнтацію за сторонами горизонту. У роботі запропоновано принцип визначення тривалості використання штучного освітлення на основі експозиції при різному розташуванні світлопрорізу в просторі, яке істотно впливає на енергоспоживання штучного освітлення приміщень. У результаті проведеного чисельного експерименту отримано прогнозований результат: найбільш енергоємним є приміщення з вертикальним світлопрорізом північної орієнтації, а найменш енергоємним - приміщення з горизонтальним світлопрорізом. Приміщення з похилим світлопрорізом має середнє значення енергоспоживання.

Ключові слова: експозиція, світлопроріз, офісне приміщення, коефіцієнт природної експозиції, освітленість, енергоспоживання. 